\title{
Regional commercial banks: problems of leadership under the current economic conditions
}

\author{
Elena Tarkhanova \\ University of Tyumen \\ Volodarskogo str. 6, 625003 Tyumen \\ Russian Federation \\ e-mail: tarhanova333@mail.ru \\ Natalia Baburina \\ University of Tyumen \\ Volodarskogo str. 6, 625003 Tyumen \\ Russian Federation \\ e-mail: natalbaburina@mail.ru \\ Svetlana Shemshurina \\ Industrial University of Tyumen, Branch in Noyabrsk \\ Industrial University of Tyumen \\ Volodarskogo street 38, 625000 Tyumen \\ Russian Federation \\ e-mail: 77365@bk.ru
}

\begin{abstract}
The processes of centralization are characteristic for the modern Russian economy. On the one hand, local companies try to go through the process of consolidation and go beyond the individual territory. On the other hand, large holdings themselves come to the regions, displacing local enterprises in the process of competition. At the same time, the events of recent years show that the largest business proved to be quite vulnerable to external negative factors - sanctions, oil price, exchange rate.

Some experts state a hypothesis that the development of regional enterprises, less dependent on external global conditions, facilitates achievement of sustainable economic growth in the future. In this regard, the problems of the development of regional commercial banks are worth being paid attention at. It is believed that the well-being of these credit institutions is the result of long-term cooperation with the local population and business. Accordingly, if this relationship is correct, then the role of regional banks as financial intermediaries is important in ensuring sustainable development of both the economies of the regions and Russia as a whole. This paper is devoted to the basics of the functioning of regional commercial banks. It discloses the nature and the main characteristics of these banks as well as identifies the positions of both domestic and foreign researchers. Moreover, it conducts an analysis of the development of regional commercial banks in their dynamics and in their comparison with a group of federal banks.
\end{abstract}

\section{Introduction}

Regional commercial banks have certain specific features, different from others (Ghosh 2015; Paulík et al. 2015; Chamberlin 2015; Cieślik et al. 2016; Gavurova et al. 2017; or Teresiené 2018). In this regard, there is a need to allocate them as a special group of Russian banks. It is necessary to take into account the role of local banks in the development of the financial and credit system of a particular region (Vorozhbit et al. 2015; or Būmane 2018). A significant burden is placed is on them to provide the subjects of the Russian Federation both with investment and with cash used to eliminate cash gaps.

By systematizing commercial banks in a group of regional banks, researchers mainly start from different indicators of their performance: the level of capitalization, the amount of equity capital, the size of the balance currency, and so on (Selyanskaya et al. 2018). The size of assets is proposed as a criterion for determining a typical regional bank: assets of up to 10 billion rubles, the provision of services in one or several regions, small and medium business as the target client audience, and the share of loans in assets of more than 50\% (Komarov 2013; or Leonov 2015). The drawbacks of this approach include the use of nominal criteria in conditions of high and moderate inflation in Russia, and the impossibility of their unambiguous quantitative measurement (Kuzmin 2015).

The distinctive features of regional banks, as a rule, include a small volume of assets, a closer relationship with the subjects of the regional economy, specialization in corporate lending. However, the use of volume of 
assets as a criterion of "regionality" can lead to the violation of cause and effect relationships, as the volume of assets is determined by the effectiveness of management and the existence of opportunities for scaling up the scope of activities. In this regard, the number of offices and regions of presence explains the volume of bank assets, and not vice versa.

Another option for allocating regional banks is specialization in working with local people and business. Some researchers point out as a criterion of regional banks their specialization in lending to small and mediumsized businesses (Andieva 2013; Zverkova 2012). However, both a special balance structure of such banks and their specialization are the result of a small volume of assets. Banks with a small volume of assets cannot give the necessary amount of loans to large borrowers due to existing regulatory restrictions on the risks of transactions with them. Since obtaining a loan involves costs for the borrower, large companies prefer to be serviced in banks that have large financial opportunities. Since regional banks are limited in the sources of raised funds (for example, issuing bonds is economically viable with significant amounts of borrowing), they maintain a large share of assets in cash and securities to minimize liquidity risks. Moreover, due to the lack of opportunities to finance regional economy projects with an acceptable level of credit risk, the bank can develop cash management services or be specialized in currency conversion operations. If the economic conditions change in the region, the bank can reorient its activities to lending to the real sector of the economy.

In the study of the information agency "Rus-Rating" regional banks are allocated according to the level of capitalization, the distribution of assets and their sources in a separate category. The disadvantage of this allocation of regional banks group is that this method reflects only quantitative results of activities. Another criterion used by experts is the availability of a control (or at least "blocking") stake in the bank from local authorities, which directly entails a special role for the credit organization in the region's life. Also, one of the categories of regional credit organizations is defined as a "municipal bank". A bank of this type is potentially capable of carrying out a full list of banking services with a focus on serving economic agents within a single municipal territory, thereby having a narrower specialization (Yanin 2002).

The purpose of this study is to assess the current state and development trends of regional banks in terms of identifying the need for their further functioning in the regional economy.

\section{Regional banks}

Regional lending institutions are also defined according to the service sector (international, national and regional banks) (Lavrushin 2010). Regional institutions in this case are necessary to include those credit organizations that serve mainly the region of their location. The municipal bank, whose activities are concentrated in the same city, is also singled out for the same reason. Historically, regional commercial banks "supported small and mediumsized businesses, together with local authorities, they lent to socially important projects" (Lavrushin 2010). It is also important that local banks at the same time had a high degree of trust among the population who prefer to invest in them rather than in other monetary institutions (Strielkowski and Höschle 2016).

Some researchers are opposed to the separate definition of the concept of a regional bank. If 'regional' is a bank that conducts business outside Moscow, then almost all leading Russian banks that have long been engaged in lending in the regions with adequate potential, can be called regional. If 'regional' means the place of registration of a bank, it is unclear why it is a special feature. The concentration and centralization of capital is not subject to internal administrative boundaries. When banking services are available and of high quality, and the partner generates trust, the consumer does not care what region the bank pays taxes in (Vernikov 2006).

In foreign practice, the credit organizations with the activities limited to a certain territory (state, land, region) are considered regional (Bernshtam and Luzanov 2001).

It should be noted that in the European legal concept the Basel-I standard paid insufficient attention to the meaning of a regional bank. Everything has changed radically in the normative approach to the organization of Basel II banking business. This approach considers the classification of commercial banks in accordance with the current processes of globalization in the banking sector. A regional bank is on the bottom of the pyramid and is registered according to the law in this particular region and operates primarily in the region, regardless of the actual economic owner of the bank and its location. The foreign normative approach distinguishes such concepts as national bank, regional bank, large financial group owning a complex of banks, etc. The same approach is followed in the US, ranking banks by regions of presence, the size of banks' total capital, the form of ownership, the link of the banking system, the legislation of particular states (Bernshtam and Luzanov 2001).

Representatives of the mechanistic approach believe that the regional bank's criterion is the location of its headquarters and most of its activities (usually more than 50\%) in this region (Burns and Stalker 1961). Meanwhile, such classification refers to the regional banks and those credit organizations that are a part of large national banking groups. In the opinion of many experts of this approach, single regional banks of Russia will sooner or later either leave as a result of market competition with the largest credit institutions, or will agree to merger or acquisition, and the priority is national banking groups. Moreover, representatives of this approach 
believe that after passing the procedure of absorption, the regional bank, if it remains independent in reporting and image, remains regional.

\section{Methodology and empirical model}

The empirical base of the study was made up of documents containing data obtained during the analysis of the Russian experience of regional commercial banks functioning. The results of statistical studies, including fundamental research, the scientific works of Russian and foreign scientists, etc., served as empirical grounds for the conclusions and summaries. A set of methods of economic research combined by a system approach to the study of this problem was used. At different stages of the work, analytical, monographic, economic-statistical, graphic, comparative, economic-mathematical methods of research were applied.

Recently, the formation and functioning of regional commercial banks have come to the front place. The resources of the regional banks usually represent the aggregate resources of the banking system of the country, thereby consolidating the regional structure of the banking system. Regional banks, of course, can be called specialized credit organizations. Each individual region has its specific economic development, therefore, the bank is forced to provide only those services that are most demanded in the region. In addition, the prerequisites for the allocation of regional banks are the features of Russia's political and economic development.

First, it is the specific of property relations. The largest enterprises of the country in the process of privatization were under the control of a limited number of financial and industrial groups with a center in Moscow. Such a trend was typical for the banking system, as credit institutions were formed at the expense of the same groups. Consequently, banks, by virtue of the remoteness of the main management apparatus, could not fully meet the needs of enterprises in the regions because of the difficulties with understanding the specifics of the situation there (Belousov 2008).

Secondly, it is a differentiated level of economic development of the regions. In the regions with 'strong' economy, there was a base for creating their own regional banks, while branches of large federal banks were opened in the 'dependent' ones.

The largest share of banks is in the Central federal district. The Far Eastern and Siberian federal districts have a very small number of banks serving the regional economy. The uneven development of regional credit institutions, due to objective economic reasons, made it impossible to extend a unified system for managing regional banking systems to all territories.

Third, it is the difference in the formation of the banks' resource base. Subsidiary banks of major Russian or foreign credit institutions had access to relatively cheap sources of funds, both in the form of transfers from parent organizations and in the form of budgetary funds. Weaker positions of regional banks have determined the need to separate them into a specific group to develop independent development strategies and create competitive operating conditions.

Fourth, it is significant structuring of banks: in the Russian banking system, along with large ones, there are also very small credit organizations. This feature predetermined the problems in the approaches to supervision and control by the Bank of Russia (unified without the differentiation of banks in terms of developmental features). A number of small banks, despite the high degree of their significance for the regional economy, could not fulfill the requirements of the regulator and was forced to cease its activities. Hence, there is a need to allocate regional banks taking into account their risks and other developmental features.

The regional segment of the Russian banking system is heterogeneous (Beloglazova 2018). There are two key groups of regional banks. The banks that are under direct or indirect control of the government of the Russian Federation constituent entities belong to the first group.

This group of banks actively promotes the implementation of investment projects that are significant for local authorities; supports local industry through concessional lending, stimulates housing construction, etc. Thus, they contribute to the solving of important economic and social problems by the regional authorities. During crisis periods such credit organizations simplify the task of stabilizing the local economy, their participation in anti-crisis programs significantly increases the effectiveness of many economic and administrative measures to overcome the crisis. At the same time, the existence of regional banks controlled by the authorities distorts the natural competitive conditions of a market economy. These credit organizations are able to use the administrative resource, and also generate risks of opportunistic, corrupt behavior, which can negatively affect the investment climate of the region and its further development. The second group is private regional banks. Their main customers are small and medium-sized businesses, providing a wide range of services to local consumers. Small regional credit organizations are maximally oriented to the interests of their consumers. Among them there are stable banks with developed infrastructure and a long history, able to adapt to changes in the regional economy, its specific features (Beloglazova 2018).

One of the important advantages of small-sized banks is the simple structure of the administrative apparatus, which does not require large expenditures for its maintenance. Local banks support the necessary conditions for the stable development of the regional economy and increase its resistance to crisis phenomena. In 
the event of an economic downturn, federal credit institutions tend to move liquidity to head structures, thereby dramatically worsening the economic situation of their branches territory. At the same time, regional banks have no choice but to save themselves and help their clients.

\section{Results and discussions}

Analysis of the dynamics of the number of federal and regional banks in Russia allows us to conclude that the number of credit institutions decreased while the rate of decline was accelerating in 2013-2015.

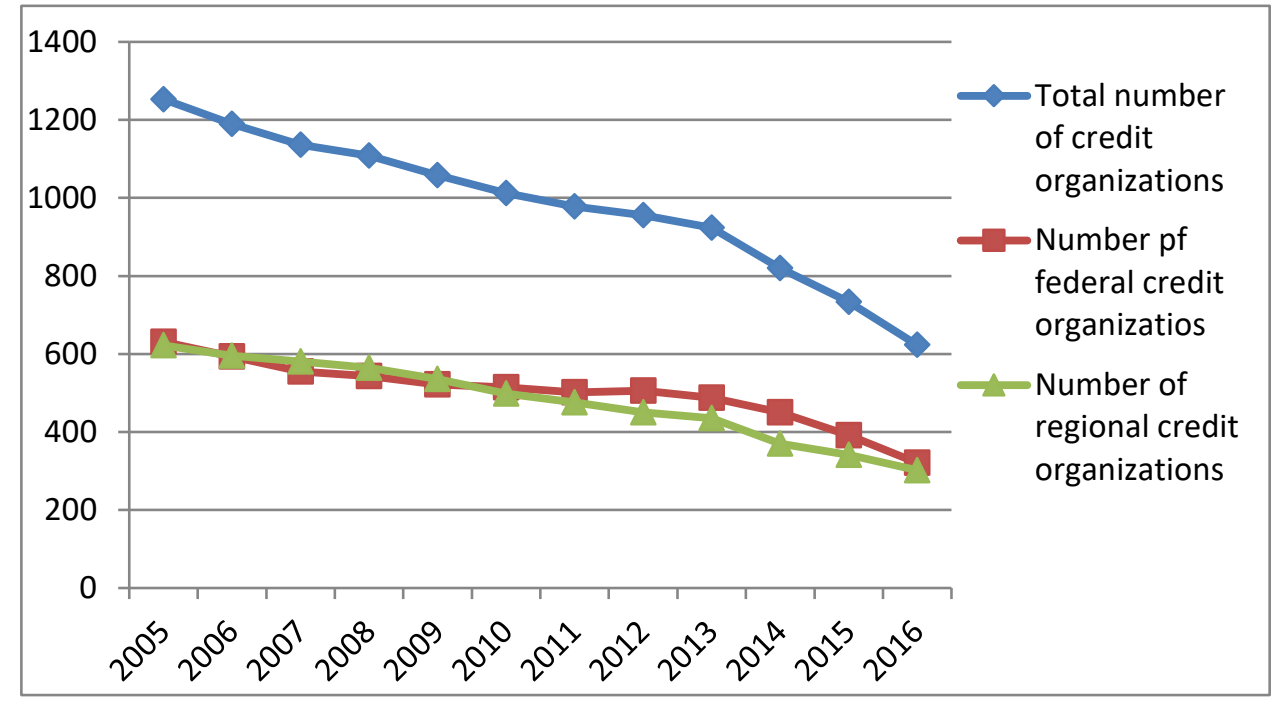

Fig.1. Dynamics of the number of credit institutions, units Source: Own results

An analysis of the profit dynamics of both types of banks indicates that it is co-directed, i.e. periods of growth and fall coincide. At the same time, the profits of federal banks are much higher than those of regional banks. However, according to the results of 2014, the profits of the federal banks significantly decreased compared to the profit of the regional banks, the gap increased by eight times, which automatically returns the banks' data to the 2009 indicator. At the same time, there is a cyclicity in the ratio between the profit of banks of different groups in 2007-2011 and 2013-2016. This is due, first of all, to the fact that in both designated crisis periods there was a decline in export prices for oil, which entailed a decline in profits of the largest Russian companies at which federal banks were serviced.

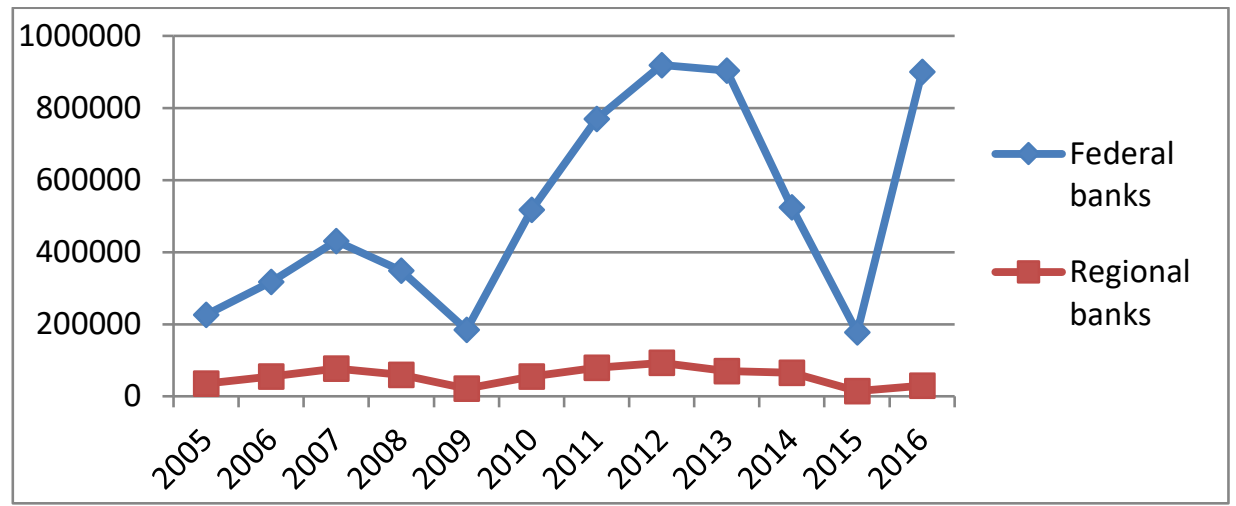

Fig. 2. Dynamics of net profit of credit institutions, in mln. rubles Source: Own results

It should also be taken into account that many of them are subsidiaries of oil and gas companies (for example, "Gazprombank"). Secondly, a significant share of the market is held by banks with state participation in Russia, especially PJSC "Sberbank" with Bank of Russia as the main shareholder. In this regard, there are grounds for proposing a thesis that in times of crisis such banks carry out activities, primarily in the interests of the socio- 
economic situation of the state, and not of their own profit as a subject of entrepreneurial activity. Hence there comes the sharp decline in profits.

The analysis of the dynamics of regional credit institutions lags far behind the federal ones. Taking into account an approximately equal number of banks of both types, it can be concluded that the regional banks' capitalization is relatively decreasing. However, during the crisis years of 2008 and 2014-2015, the share of assets of regional credit institutions comparing to the federal ones increased, which indicates greater resilience to external economic factors. It should be noted that following the results of 2016, for the first time in the last 12 years of observations, the total amount of assets of credit institutions in Russia decreased comparing to the previous year. The reasons for this change are not only the overall impact of the economic downturn, but also violations of the activities of credit institutions that the Bank of Russia identified.

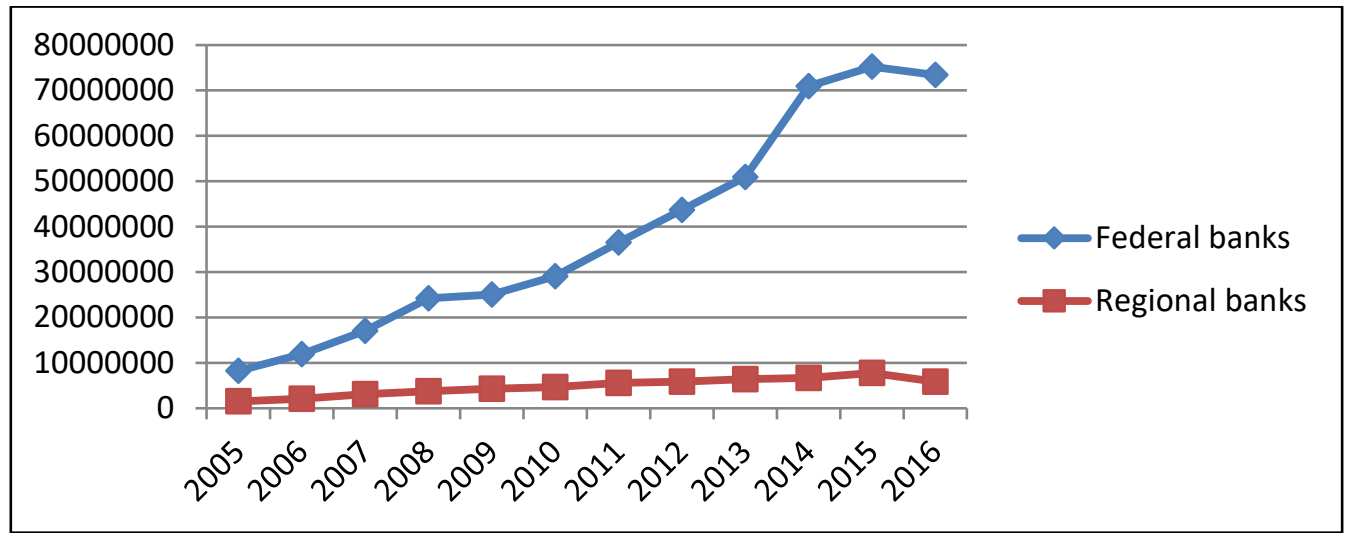

Fig. 3. Dynamics of assets of credit institutions, in mln. rubles Source: Own results

The analysis of the profitability of federal and regional credit organizations assets reflects the following facts: 1) the return on assets of regional banks is lower in a stable period (2010-2013); 2) in past crisis periods, the profitability of regional banks fell more strongly than the profitability of federal banks.

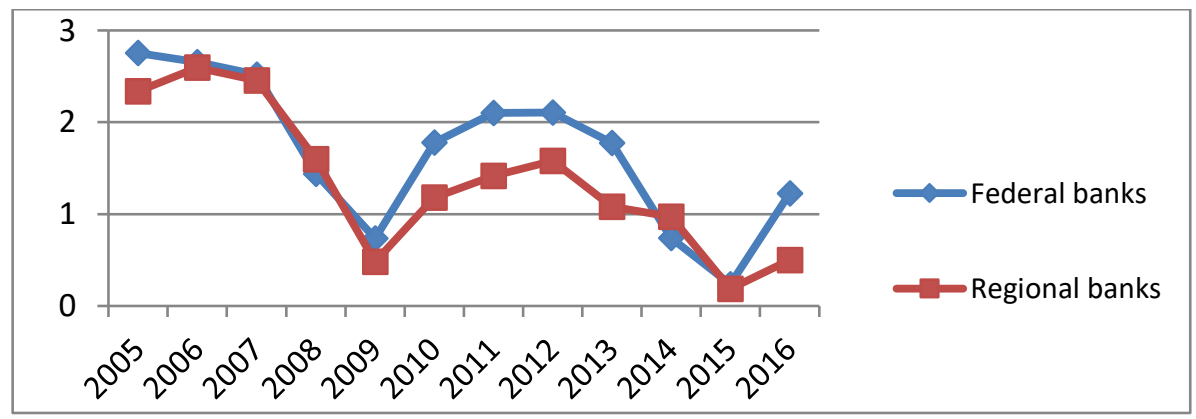

Fig. 4. Return on assets of regional banks, in \% Source: Own results

The fact that in 2014 the position of regional banks has improved could be explained by the fact that a number of federal banks faced the problem of obtaining financial resources from abroad. Individual banks were directly under sanctions, others faced the problem of trust. As a result, there was a decrease in the inflow of liabilities, their appreciation. A number of banks were forced to pay off foreign currency loans without the possibility of on-lending. This led to a strong decline in profitability. Although, regional commercial banks initially had little access to foreign loans, so the consequences were less negative for them. This circumstance proves the importance of regional banks as an institution for the stable development of an institution less dependent on external borrowing. At the same time, federal banks, having a greater resource base, are able to restore profitability faster.

Comparing the dynamics of profit and assets with some macroeconomic indicators (monthly data for the period of 2011-2016 (72 observations for each indicator), according to the stationary form), it is worth noting that such significant interrelation of indicators (from 0 to $1 ; 1$ - variables are absolutely identical in the change, the values +/- show the direct / reverse relation). There is practically no connection between assets and profitability with the RTS and MICEX indices. 
Table 1. Correlation of indicators

\begin{tabular}{|l|l|r|r|r|}
\hline & $\begin{array}{l}\text { Assets of } \\
\text { federal banks }\end{array}$ & $\begin{array}{l}\text { Assets of } \\
\text { regional banks }\end{array}$ & $\begin{array}{l}\text { Profitability of } \\
\text { federal banks }\end{array}$ & $\begin{array}{l}\text { Profitability of } \\
\text { regional banks }\end{array}$ \\
\hline $\begin{array}{l}\text { Price of Brent crude } \\
\text { oil }\end{array}$ & $-0,54$ & $-0,05$ & 0,73 & 0,62 \\
\hline RTS Index & $-0,30$ & 0,07 & 0,24 & 0,15 \\
\hline $\begin{array}{l}\text { Average monthly } \\
\text { exchange rate of } \$\end{array}$ & 0,68 & 0,09 & $-0,75$ & $-0,59$ \\
\hline
\end{tabular}

Source: Own results

The strongest correlation between the dynamics of federal banks' assets is observed with the dollar exchange rate. The main reason for this correlation is that a significant part of the assets of federal banks is in foreign currency. At the same time, regional banks have mainly ruble-denominated assets, so there is virtually no connection between the average monthly dollar exchange rate and assets. There is also a clear correlation between the price of Brent crude oil and the assets of federal banks. This can be explained, in particular, by the fact that federal banks are engaged in servicing (crediting) the largest exporting companies and some are also their subsidiaries. For the same reason, there is no connection between the assets of regional banks and the price of oil.

There is strong correlation between profitability of federal and regional banks and the average monthly dollar exchange rate and the price of Brent oil. Negative relationship with the dollar rate is due to the fact that the weakening of a ruble is usually associated with a decrease in the price of oil, i.e. a decrease in income from oil and gas revenues, which entails losses of oil exporting companies and a reduction in the 'oil and gas' revenues of the state budget, which affects all sectors of the economy along the chain. The depreciation of a dollar is intended to preserve revenues from the sale of petroleum products in rubles, but this is not fully realized, and, moreover, leads to a rise in the cost of imported goods, i.e. in general, there are negative effects on the economy. The positive correlation with the price of Brent oil reflects correspondingly the opposite phenomena - the increase in the price of oil has a beneficial effect on the Russian economy.

It is important to note that federal banks are more sensitive to the mentioned deterioration of the situation, which is proved by a stronger correlation of their profitability with the dollar and Brent oil prices comparing to regional banks. In addition, regional banks, as mentioned earlier, practically did not practice external borrowing.

\section{Conclusions}

Based on the conducted research, the main problems of regional commercial banks can be determined as: insufficient capitalization; low competitiveness; close relationship of competitive banks with exporters and / or federal state structures. At the same time, regional banks have a number of advantages, in particular, low dependence on external borrowing; more accurate knowledge of the region's economy; close interaction with local authorities. understanding the nature of the local economy, its customers and their interests, provides an opportunity for regional credit institutions to realize competitive advantages over federal banks. Clients of local banks interact on an ongoing basis with managers and employees of the credit institution. The offered banking services are made with the greatest possible consideration of the needs of clients and are personified. Individual approach allows developing special conditions for banking operations for almost everyone. Regional banks are ready to lend to small and medium-sized enterprises, with temporarily unstable financial position. Although their shareholders own significant property, the prospects for the enterprise development are optimistic from the point of view of the head of the credit institution. Local banks actively participate in the programs of the region administration on preferential lending, and in social programs. The prejudiced attitude of regional clients to Moscow and foreign banks plays not the least role. Considering the above, in our opinion, regional banks will be able to continue developing harmoniously in the banking system of the Russian Federation.

\section{References}

Andieva EV (2013) Banki regiona: funktsionirovanie i razvitie [Regional banks: functioning and development]. Prostranstvo Ekonomiki 3(3):116-121.

Baburina NA, Tarkhanova EA, Fedorova OB (2017) Innovational approaches to attracting people savings in the modern economy. Marketing and Management of Innovations 3:187-197. doi: 10.21272/mmi.2017.3-18

Būmane I (2018) The methodology of the statement of comprehensive income and its impact on profitability: the case of Latvia. Entrepreneurship and Sustainability Issues 6(1):77-86. doi: 10.9770/jesi.2018.6.1(6) 
Beloglazova GN, Dengi. Kredit. Banki [Money. Credit. Banks], $1^{\text {st }}$ edn. (Moscow: Higher Education, 2012), 229 p.

Belousov AZh (2008) Rol' kommerchekish bankov v invetirovanii ekonomiki regiona [Role of commercial banks in investment into the economy of regions]. Vestnik TGU 12:508-518.

Bernshtam ES, Luzanov AN, Regionalye aspekty organizatsii i gosudarstvennogo regulirovanya bankovskoi sferi: zarubezhnyi I rossiystye podkhody [Regional aspects of organization and regulation of banking sphere: foreign and Russian approaches], $1^{\text {st }}$ edn. (Moscow: Editorial, URSS, 2001), 104 p.

Burns T, Stalker G, The Management of Innovation, $1^{\text {st }}$ edn. (Tavistock, London, 1961), 250 p.

Cieślik A, Michałek J, Mycielski J (2016) Globalization, international trade, and human development: a case of Central and Eastern Europe. Czech Journal of Social Sciences, Business and Economics 5(2):6-15. doi: 10.24984/cjssbe.2016.5.2.1

Chamberlin G (2015) Coordinating Monetary and Fiscal Policies in the Open Economy. International Economics Letters 4(1):15-25. doi: 10.24984/iel.2015.4.1.2

Gavurova B, Belas J, Kocisova K, Kliestik T (2017) Comparison of Selected Methods for Performance Evaluation of Czech and Slovak Commercial Banks. Journal of Business Economics and Management 18(5):852-876 doi:10.3846/16111699.2017.1371637

Ghosh A (2015) Banking-industry specific and regional economic determinants of non-performing loans: Evidence from US states. Journal of Financial Stability 20:93-104. doi: 10.1016/j.jfs.2015.08.004

Komarov SV (2013) Regionalye banki: problemy i perspektivy modernizatsionnogo razvitya [Regional banks: problems and perspectives of the modernization development], Economics and Modern Management: theory and practice, materials from the XXVI International Conference, Novosibirsk, SibAk

Kuzmin E (2015) "Individual" scaling and overall evaluation of system uncertainty. Modern Applied Science 9(3): 34-45. doi: 10.5539/mas.v9n3p34

Lavrushin IO, Dengi, kredit, banki [Money, credit, banks], $1^{\text {st }}$ edn. (Knorus, Moscow, 2010), 320 p.

Leonov MV (2015) Regional banks in the Russian banking system. Prostranstvennaya Ekonomika 2:116-131. doi: $10.14530 / \mathrm{se} .2015 .2 .116-131$

Paulík J, Kombo F, Ključnikov A (2015) CSR as a driver of satisfaction and loyalty in commercial banks in the Czech Republic. Journal of International Studies 8(3):112-127. doi: 10.14254/2071-8330.2015/8-3/9

Selyanskaya G, Finogenova Y, Strielkowski W (2018) Factor Analysis of Economic Leadership Peculiarities of Countries and Regions Around the World. In: Strielkowski W, Chigisheva O (eds) Leadership for the Future Sustainable Development of Business and Education. Springer Proceedings in Business and Economics. Springer, Cham, pp. 213-222. doi: 10.1007/978-3-319-74216-8_22

Strielkowski W, Höschle F (2016) Evidence for economic convergence in the EU: The analysis of past EU enlargements. Technological and Economic Development of Economy 22(4): 617-630. doi: $10.3846 / 20294913.2014 .890138$

Teresiené D (2018) Performance measurement issues in central banks. Entrepreneurship and Sustainability Issues 6(1):176-189. doi: 10.9770/jesi.2018.6.1(12)

Vorozhbit O, Danilovskikh T, Kuzmicheva I (2015) Assessment of proper capital sufficiency of regional commercial banks. Mediterranean Journal of Social Sciences 6(5):71-77. doi: 10.5901/mjss.2015.v6n5s3p71

Vernikov AV (2006) Regional Complex. http://bo.bdc.ru/2006/6/slova.htm Accessed 22 Jul 2018

Yanin VV (2002) Osnoyy funktsionirovanya i ustoychivost regionalnogo banka [Basics of functioning and stability of a regional bank]. Dissertation for defence of the Candidate of Sciences, Saratov, $155 \mathrm{p}$.

Zverkova TN, Regionalye banki v transformatsionnoi ekonomike: podkhody k formirovaniu kontseptsii razvitya [Regional banks in transformational economy: approaches to the formation of the development concepts], $1^{\text {st }}$ edn. (OOO Agenstvo Pressa, Orenburg, 2012), 214 p. 